\title{
The Techniques Used for Reading Comprehension Instruction, Case Study Albania.
}

Irena Shehu

PhD Candidate, European University of Tirana, ALBANIA,

aneri-87@live.com

\section{Abstract}

Reading Comprehension is a crucial component of second language acquisition. As a core part of language learning it is, obviously, not an effortless process. Students often complain of not understanding a text, therefore they fail in answering to the comprehensive questions. Unfortunately, this is a reality evidenced and proven from unsatisfactory results of students in English Language Matura Exam in Albanian high schools, as these students have been the objective of this study. In this context, one certainly may ask for kinds of techniques used to teach Reading Comprehension. Thus the research questions used in this study are:

1. Are there used the right techniques to teach Reading Comprehension in Albanian high schools?

2. Which are the theories and best techniques of Reading Comprehension recommended for every teacher to use in his classroom?

Concerning the first questions we can give an answer with the help of the questionnaires. Actually there a lot of theories and studies related to this topic which will be used as an important source. It is necessary to mention some of them like: Manyak and Bayer,Mckeown others from National Reading Pannel, because their studies will serve as a very important mean to answer the second question. The last but not the least focus is the questionnaires as their results are good detectors of techniques and way used in Reading Comprehension classes, in Albania. This would direct us to a proper strategy for problem solving and improving the situation. In this way the methodology used is in the form of questionnaires which were submitted to students from three different high schools in Albania and filled by around 200 students.

Keywords: Reading, comprehension, techniques, ways, improve,

\section{Introduction}

English Language is one of the most important things to learn nowadays in Albania. This is due to the new policies and regulations of the Ministry of Education and Sports which has imposed new rules even to the students of the high school, who in order to get graduated have to successfully pass the English Language Test.

Actually there is not a satisfactory level of students' outcome as they have shown a lot of Reading Comprehension problems concerning second language acquisition, respectively English Language. But the essential focus of this study is not the difficulties but the techniques as the main reasons of failure and success in Reading Comprehension.

One may ask why teaching reading-comprehension techniques are important?

According to Malena \& Atwood Coker(1987) it is common for students to have difficulties with reading comprehension, and the need to provide students with concrete strategies for approaching reading tasks is well-documented. Other important scholars like Dowhower, 1999; Duffy et al, 1987; Long \& Long, 1987 suggest that students skilled in reading comprehension are able to interact with course material actively through paraphrasing, summarizing, and relating the material to personal experience, while students less-skilled in reading comprehension can only underline or reread passively without the use of specific strategies.

Another important argument given by important scholars is that students who fail to employ reading strategies tend to experience difficulty inferring conceptual meaning, relating to what they have read, self-monitoring their learning and understanding, and evaluating texts for clarity and consistency (Duffy et al, 1987; Long \& Long, 1987; Underwood, 1997). These difficulties can also lead to decreased engagement in the current reading task, as well as a lack of motivation when approaching new reading tasks (Dowhower, 1999).

In this context it is necessary to make a proper study about this process, the techniques used during reading comprehension. First of all we need to have an understanding of the theories behind reading comprehension, as well as a 
working knowledge of some important strategies that can be used in the classroom to increase reading comprehension. Thus in this paper, initially we are going to focus on three important theories on reading comprehension: the Schema Theory; Mental Models, and the Propositional Theory, and four categories of strategies to improve reading comprehension based on these theories: Preparational, Organizational, Elaboration, and Monitoring.

Thus, in order to be clearer the research questions used in this study are:

1. Are there used the right techniques to teach Reading Comprehension in Albanian high schools?

2. Which are the theories and best techniques of Reading Comprehension recommended for every teacher to use in his classroom?

This study explores comprehension strategies and techniques used in Albanian high schools and the benefits of using the proper strategies. It is also examined the descriptions of each type of comprehension strategy and instructional implications for teaching comprehension.

\section{Review of literature and theories of Reading Comprehension}

When it comes to theories related to reading comprehension strategies, of course, there is an important name, Gunning, which identifies three main theories; Schema Theory, Mental Models, and Proposition Theory.

The first theory is Schema Theory. In his study in1996, Gunning defines a schema as the organized knowledge that one already has about people, places, things, and events.

The second theory is Mental Model Theory. According to Gunning this model can be thought of as a mind movie created in one's head, based on the reading content. The reader focuses in on the main character and creates a mental model of the circumstances in which the character finds him or herself. Furthermore Perkins (1991), another important scholar supports and gives arguments on this idea. He states that the information gives the teacher insight on the student's knowledge gaps and misconceptions, therefore allowing them to help students reconstruct a more accurate picture.

The third theory is Proposition Theory. This theory involves the reader constructing a main idea or macrostructure as they process the text. These main ideas are organized in a hierarchical fashion with the most important things given the highest priority to be memorized (Gunning, 1996).

Other important theories and studies on strategies used to comprehend a text.

Let us still continue with Gunning. Furthermore he identifies four main types of comprehension strategies, Preparational, Organizational, Elaboration and Monitoring.

Preparational strategies are those strategies that activate prior knowledge about a particular topic. This method is used to get students thinking about the topic they are about to work on. It is much easier to retain knowledge about a subject when the student is familiar with the subject area.

Predicting the text is considered ad the most important type of Preparational strategy which is about previewing parts of the text to be read. Gunning states 'as the students are thinking about what will happen based on their knowledge of the subject and the book, they focus their thoughts on the assignment to come, which leads to better comprehension.'

Organizational strategies

Gunning (1996) describes these strategies as the process of selecting important details and building relationships from them. Thus here there are included these type of strategies: identifying the main idea and topic sentences, classifying information, deciding which information is relevant, sequencing and summarizing. Each of the above strategies is complex and often methods for improving them need to be taught starting from basic ideas and gradually getting more difficult.

Elaboration 
Gunning (1996) describes elaboration as an additional processing of the text, by the reader, which may increase comprehension. It is about creating links between the text and the reader's background knowledge of the subject. The most important types of elaboration strategies are making inferences, picturing images and asking questions.

Huffman (1998), a very important scholar identifies K-W-L as an elaboration strategy, which connects background knowledge to the topic to be addressed. K-W-L is an acronym for the three steps of the procedure: describing what we Know, what we Want to know, and what we Learned. The first two steps are completed before the project has begun, to assess background information, and the third step is completed afterward to make the connections.

Monitoring

Gunning (1996) refers to monitoring as being aware of one's own mental process when reading. Monitoring is an advanced technique that involves a great deal of independent thinking. Monitoring occurs when a reader is aware that they do not understand what was just read. Monitoring is knowing when to use the three other types of reading comprehension strategies.

\section{Methodology}

\section{Study case key points}

Location: three different Albanian High schools

Method: quantitative in the form of questionnaires (see appendix 1).

Focus :

-students' opinion about techniques they use to deal with Reading Comprehension part in their English class

- the students` familiarity with techniques

\section{Sample}

When selecting the students for this study, there were chosen students from three different high school of Albania,, "Havzi Nela" high school, Kukes, "Kostandin Kristoforidhi", Elbasan, "Hydajet Lezha", Lezhë. This was partly to minimize the risk of different schools having different policies of teaching, English level etc.

In each school there were a few students that could not attend when the questionnaire was handed out for various reasons. In total the questionnaires were filled in by 200 students.

\section{Questionnaires}

This study was done with the help of questionnaires hand out to the students in order they give opinions about the techniques they use for Reading Comprehension activities.

The entire survey, the introduction as well as the questions, was written in Albania, This was because the questionnaire was not intended to test their understanding, but to get as reliable answers as possible by avoiding misunderstandings as some of the terms are difficult enough in the students' first language. A further reason was that at the end of the questionnaire there were two open-ended questions, and by being allowed to write in their first language, students would feel more comfortable writing and giving suggestions.

The questionnaire consisted of an introduction informing each student of the general subject of the survey, namely to investigate their opinions of techniques they use during reading comprehension process. It was also declared that participation was voluntary, and that they could opt out at any time without being questioned why. In the last part of this short introduction, students were kindly requested to be sincere while giving an answer. 
In the questionnaire there were mainly two types of questions. The first type was multiple-choice questions, and here students were told to give the answer they thought agreed with their own opinions.. For the second type of question, the closed ones, there was rating using words, like Every day, Often, Rarely, and Never; or using numbers as in this example: Choose a rating of frequency 1 (never) to 5 (always) for the reading comprehension strategies below.

The students were here asked to circle only the one option they thought was closest to their opinion. ]

Since these two types of questions were closed (and semi-closed), there was a need for the students to be able to say something in their own words at the end of the questionnaire. So in addition, as mentioned above, there were two openended questions at the end. In the first question, they were asked to give their opinion about any other reading comprehension technique and in the second they had to list the activities they do most frequently in the class when dealing with Reading Comprehension.

\section{RESULTS AND ANALYSIS}

As mentioned above, the results will come with the help of a questionnaire filled by Albanian high school students. In this way it would be able to see the way they deal with Reading Comprehension part during English classes.

The focus will be drown on two important issues which will give a big contribution in finding the answer of the research questions mentioned in the beginning of this study.

Thus the objectives of the questionnaires are to find out:

the students' opinion about techniques they use or are offered to deal with Reading Comprehension part in their English class

-the students` familiarity with techniques

It is important to highlight once again that the questionnaires were filled by 200 students and answers below are given based on this data.

\section{Results for the first objective}

When asked about the way they deal with Reading Comprehension activities, first they have to choose alternatives which best fits their reality. First they were asked to circle the activities their teacher does to help them when dealing with Reading comprehension. The answers were shown in the chart below, where on the left side it is the number of students choosing of the alternatives on the down side.

Chart 1. Student's opinion about what their teacher does to help them when dealing with Reading comprehension 


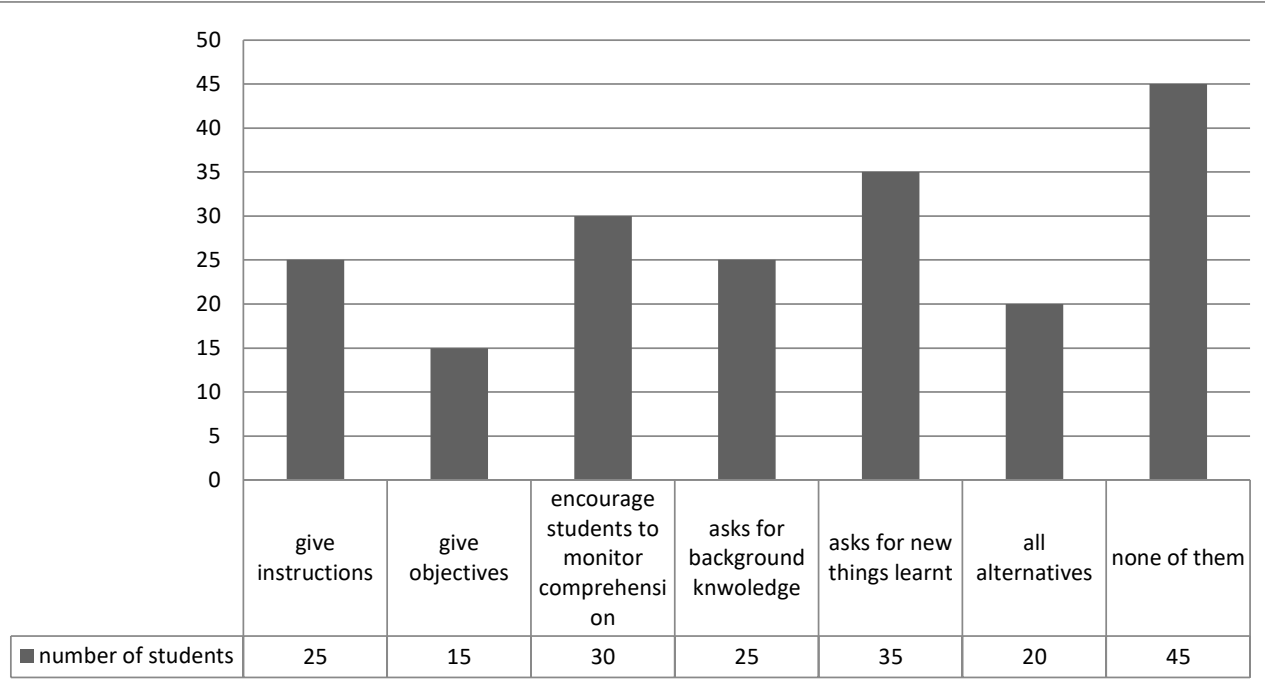

Later on students were asked about techniques used by the teacher when students face difficulties. The answers were:

Chart 2. Techniques used by the teacher when students face difficulties

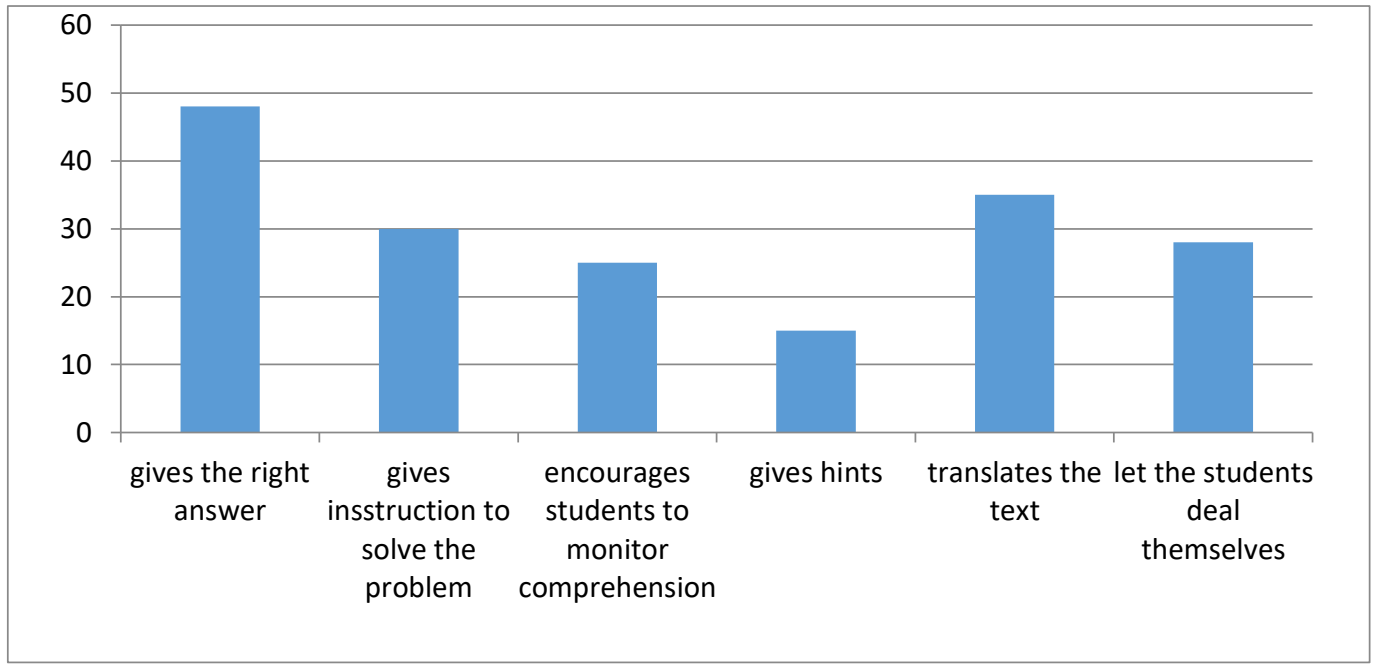


Another important question was:"After reading a text the teacher asks you to: ". They replied in this manner as shown in chart 3.

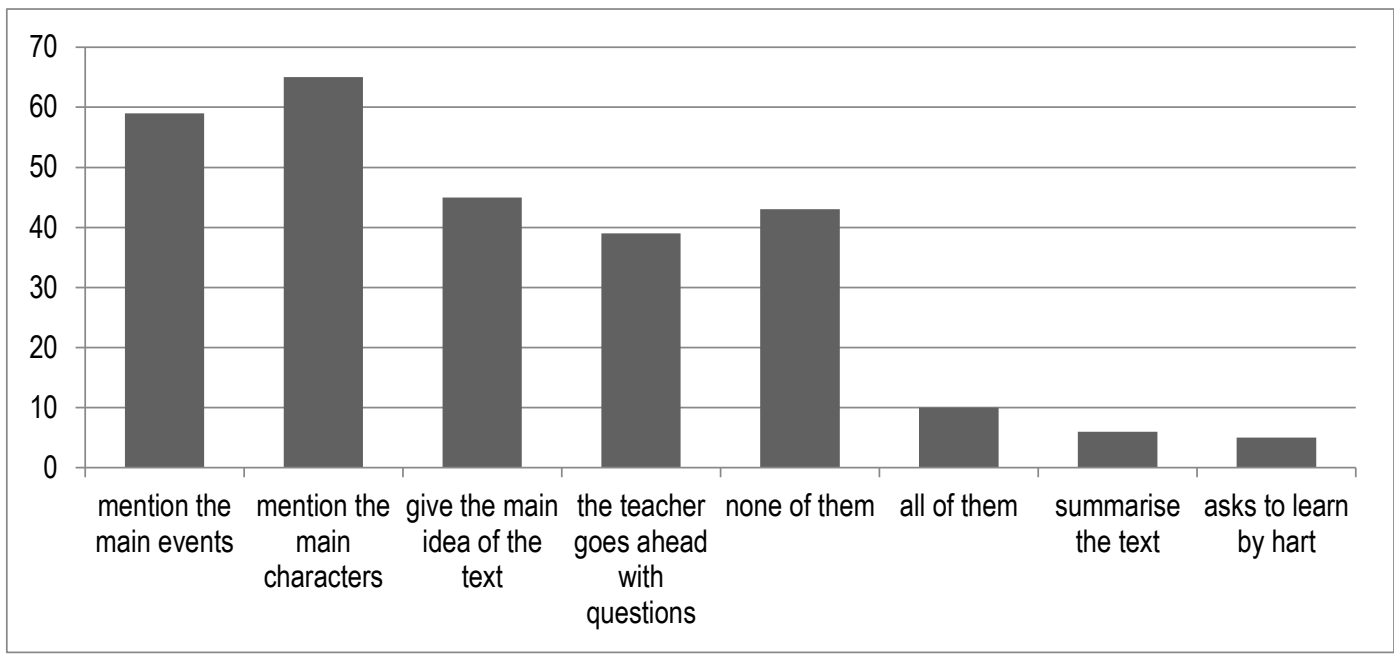

They were also asked about the time at their disposal and the results were:

35 yes
70 - no
60 - a little
30 - enough
10 - don't know

This indicates that even the time at their disposal is not enough. Thus teachers need to plan reading classes more properly.

Another type of questions is like the following, where students have to choose a number rating frequency, from 1 meaning Never to 5 meaning Always. These questions are about student's techniques or methods when dealing with Reading Comprehension activities, The results will be shown on a table below:

1. I read quickly through the story to get the general idea before I read the story closely.

$$
\begin{array}{lllll}
1 & 2 & 3 & 4 & 5
\end{array}
$$

2. When I come to a part of the story that is hard to read, I slow my reading down.

$$
\begin{array}{lllll}
1 & 2 & 3 & 4 & 5
\end{array}
$$

3. I am able to tell the difference between important story parts and less important details.

$$
\begin{array}{lllll}
1 & 2 & 3 & 4 & 5
\end{array}
$$

4. When I read, I stop once in a while to go over in my head what I have been reading to see if it is making sense.

$$
\begin{array}{lllll}
1 & 2 & 3 & 4 & 5
\end{array}
$$

5. I adjust the speed of my reading by deciding how difficult the story is to read.

$$
\begin{array}{lllll}
1 & 2 & 3 & 4 & 5
\end{array}
$$

6. I stop once in a while and ask myself questions about the story to see how well I understand what I am reading. 


\section{$\begin{array}{lllll}1 & 2 & 3 & 4 & 5\end{array}$}

7. After reading a story, I sit and think about it for a while to check my memory of the story parts and the order of the story parts.

$$
\begin{array}{lllll}
1 & 2 & 3 & 4 & 5
\end{array}
$$

8. When I get lost while reading, I go back to the place in the story where I first had trouble and reread.

$$
\begin{array}{lllll}
1 & 2 & 3 & 4 & 5
\end{array}
$$

9. When I find I do not understand something when reading, I read it again and try to figure it out.

$$
\begin{array}{lllll}
1 & 2 & 3 & 4 & 5
\end{array}
$$

10. When reading, I check how well I understand the meaning of the story by asking myself whether the ideas fit with the other information in the story.

$$
\begin{array}{lllll}
1 & 2 & 3 & 4 & 5
\end{array}
$$

11. I find it hard to pay attention when I read.

$$
\begin{array}{lllll}
1 & 2 & 3 & 4 & 5
\end{array}
$$

12. To help me remember what I read, I sometimes draw a map or outline the story.

$$
\begin{array}{lllll}
1 & 2 & 3 & 4 & 5
\end{array}
$$

13. To help me understand what I have read in a story, I try to retell it in my own words.

$$
\begin{array}{lllll}
1 & 2 & 3 & 4 & 5
\end{array}
$$

\begin{tabular}{|c|c|c|c|c|c|c|}
\hline Rates & 1 & 2 & 3 & 4 & 5 & \\
\hline 1 & 90 & 45 & 40 & 10 & 15 & \multirow{7}{*}{$\begin{array}{l}\text { Total } \\
\text { number } \\
\text { of } \\
\text { students }\end{array}$} \\
\hline 2 & 20 & 10 & 15 & 30 & 125 & \\
\hline 3 & 44 & 42 & 34 & 55 & 25 & \\
\hline 4 & 36 & 54 & 23 & 53 & 34 & \\
\hline 5 & 30 & 30 & 25 & 45 & 70 & \\
\hline 6 & 23 & 56 & 51 & 45 & 25 & \\
\hline 7 & 47 & 45 & 73 & 20 & 15 & \\
\hline
\end{tabular}

14. I learn new words by trying to make a picture of the words in my mind.

$\begin{array}{lllll}1 & 2 & 3 & 4 & 5\end{array}$

15. When reading about something, I try to relate it to my own experiences.

$$
\begin{array}{lllll}
1 & 2 & 3 & 4 & 5
\end{array}
$$

Chart 4. Result of the questionnaire about student's techniques or methods when dealing with Reading Comprehension activities 


\begin{tabular}{|l|l|l|l|l|l|}
\hline 8 & 8 & 37 & 60 & 40 & 55 \\
\hline 9 & 48 & 45 & 37 & 40 & 30 \\
\hline 10 & 45 & 47 & 83 & 15 & 10 \\
\hline 11 & 13 & 25 & 32 & 70 & 60 \\
\hline 12 & 84 & 76 & 20 & 10 & 10 \\
\hline 13 & 5 & 50 & 44 & 38 & 64 \\
\hline 14 & 14 & 42 & 37 & 48 & 59 \\
\hline 15 & 57 & 34 & 45 & 30 & 34 \\
\hline
\end{tabular}

Another objective of the survey is the familiarity of students with some of the most important techniques used in reading comprehension.

Students were asked to choose alternatives about this question:" Which of the above techniques do you know?". The answers are shown in the chart below.

Chart 5.The familiarity of students with some of the most important techniques used in reading comprehension

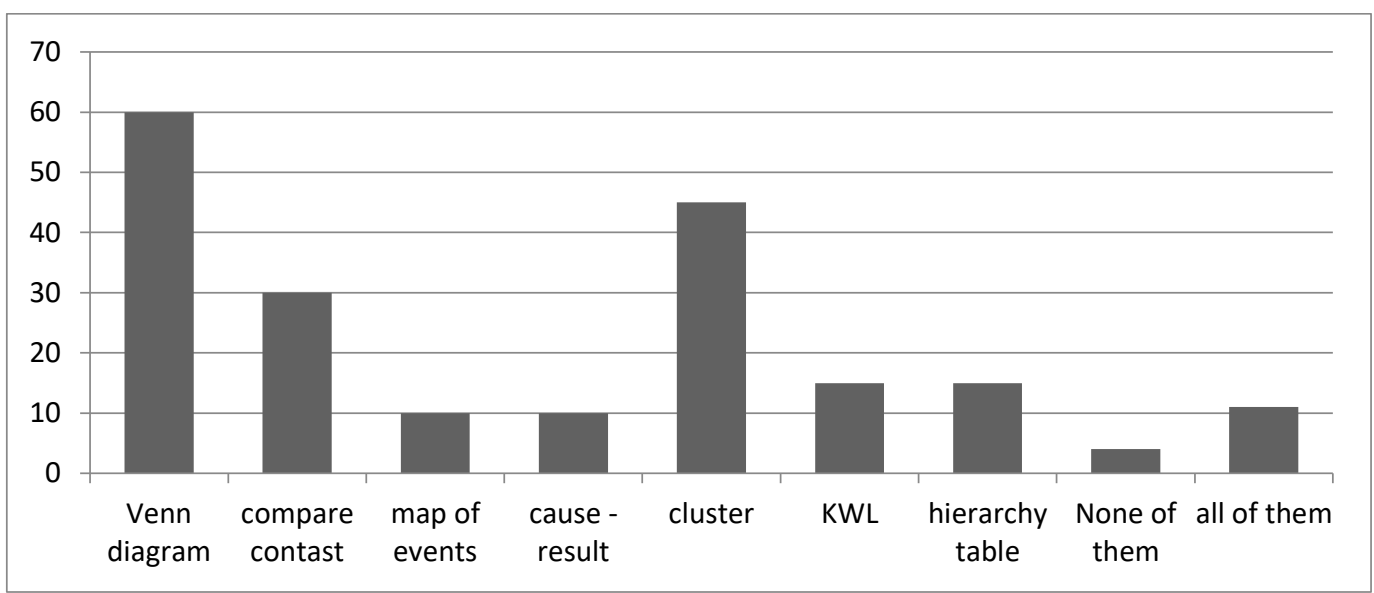

Based on the results of our survey, students in high schools of Albania have a lot of difficulties dealing with Reading Comprehension in English classes, this is due to several factors, but the most important of all is the lack of the right techniques. Thus we can say that there are not used the right techniques, furthermore some of the students to not know what a technique is. In this context teachers need to do more to promote and encourage students using different techniques to facilitate their way toward text comprehension.

\section{RECCOMANDATION}

As mention above it is highly recommended that teachers use and promote some of the most relevant reading comprehension techniques on their English classes.

Thus, first of all it is important to encourage students to monitor comprehension, by making them aware of what they do understand, identifying what they do not understand and making them use appropriate strategies to resolve problems in comprehension 
Secondly, let us refer to Metacognition. It can be defined as "thinking about thinking." Before reading, students might clarify their purpose for reading and preview the text. During reading, they might monitor their understanding, adjusting their reading speed to fit the difficulty of the text and "fixing" any comprehension problems they have. After reading, they check their understanding of what they read.

Third, it is broadly advised to use graphic and semantic organizers. As discussed student are not so familiar with graphic and semantic organizers. Some of the most relevant ones are:Here are some examples of graphic organizers:

\section{Venn-Diagrams , Storyboard/Chain of Events , Story Map ,Cause/Effect}

Anoher important technique of good value to be used is:" Answering questions". There are four different types of questions:"Right There", "Think and Search","Author and You","On Your Own"

Another last important technique is summarizing. It requires students to determine what is important in what they are reading and to put it into their own words. Instruction in summarizing helps students:

$$
\begin{aligned}
& \text { Identify or generate main ideas } \\
& \text { Connect the main or central ideas } \\
& \text { Eliminate unnecessary information } \\
& \text { Remember what they read }
\end{aligned}
$$

\section{CONCLUSION}

As a conclusion it is important to answer the two research questions.

Concerning the first, if there are used the right techniques to teach Reading Comprehension the results indicated that teachers try to use the techniques but still it is not enough and there is a lot to do in this aspect.

Another important issue is the familiarity of students with the most important Reading Comprehension techniques. Based on the results of the questionnaires a lot of students don't know at all what a technique is. Some of them declared that they are not familiar with anyone in the given list, which indicates the lack of use in English classes. In this context it should be more encouragement by the teachers to promote the use of Reading Comprehension techniques such as graphic organizers ( Venn diagrams, story map, Cause /effect), KWL etc.

In this way the route toward excellent results on Reading Comprehension would be facilitated and students would be more motivated.

\section{References}

[1] Armstrong, Thomas. (1994). Multiple Intelligences in the Classroom. Chapter 6, 72.

[2] Dowhower, S.L. (1999). Supporting a strategic stance in the classroom: A comprehension framework for helping teachers help students to be strategic. The Reading Teacher, 52, 672-688.

[3] Duffy, G.G., Roehler, L.R., Sivan, E., Rackliffe, G., Book, C., Meloth, M.S., et al. (1987). Effects of explaining the reasoning associated with using reading strategies. Reading Research Quarterly, 22(3), 347-368.

[4] Gunning, Thomas G. (1996). Creating Reading Instruction for All Children. Chapter 6, 192-236.

[5] Huffman, Lois E. (1998). Spotlighting Specifics by Combining Focus Questions With K-W-L. Journal of Adolescent and Adult Literacy, Issue 6, 470-471.

[6] Katims, David S. (1997). Improving the Reading Comprehension of Middle School Students in Inclusive Classrooms. Journal of Adolescent and Adult Literacy, Issue 2, 116-124. 
[7] Keene, E. \& Zimmerman, S. (1997). Mosaic of thought: Teaching comprehension in a reader's workshop.Portsmouth, NH: Heinemann.

[8] Kitao, Kathleen S. (1990). Textual Schemata and English Language Learning. Cross Currents, Issue 3, 147-155.

[9] Long, J.D. \& Long, E.W. (1987). Enhancing student achievement through metacomprehension training. Journal of Developmental Education, 11(1), 2-5.

[10] Malena, R.F. \& Atwood Coker, K.J. (1987). Reading *O*prehension: The missing elements. Journal of Developmental Education, 10(3), 24-25, 35

[11] Ogle, D.M. (1986). K-W-L: A teaching model that develops active reading of expository text. The Reading Teacher, 39(6), 564-570.

[12] Pearson, P.D. (1985). Changing the face of reading comprehension instruction. The Reading Teacher, 38(8), 726737.

[13] Perkins, D.N. (1991). Educating for Insight. Educational Leadership. Issue 2, 4-9.

[14] Pressley, M., Ghatala, E.S., Woloshyn, V, \& Pirie, J. (1990). Sometimes adults miss the main ideas and do not realize it: Confidence in responses to short-answer and multiple-choice comprehension questions. Reading Research Quarterly, 25(3), 232-249.

[15] Strunc, I. (2004, March). GED 2002 teachers' handbook of lesson plans. Florida TeachNet. Retrieved March 28, 2005, from www.floridatechnet.org/GED/LessonPlans/ LanguageArtsReading/readinglesson34.pdf

[16] Tovani, C. (2000). I read it, but I don't get it: Comprehension strategies for adolescent readers. Portland, ME: Stenhouse Publishers.

[17] Underwood, T. (1997). On knowing what you know: Metacognition and the act of reading. The Clearing House, $71(2), 77-80$.

[18] Walker, B. (2000). Diagnostic teaching of reading: Techniques for instruction and assessment (4th ed.). Upper Saddle River, NJ: Merrill.

\section{Appendix}

The questionnaire in Albanian language.

Pyetësor mbi : Strategjite e ofruara në klasë për të lexuar dhe analizuar një tekst në gjuhë të huaj.

\section{Qarko pikat që perdoren nga mesuesi kur analizoni nje tekst:}

a) U jep studenteve nje objektiv apo qellim te caktuar

b) I udhezon studentet e te mesojne

c) Ndihmon student te mendojne aktivisht

d) Inkurajon studentet te monitorojne te kuptuarin e tyre rreth ne teksti te caktuar]

e) I pyet studentet cfare dine rreth asaj teme perpara se ta lexojne ate

f) I pyet student nëse mesuan dicka te re nga e lexuara

g) Të gjitha këto

h) Asnjëra nga këto

i) Tjetër

2.Cilat nga mënyrat e me poshtme perdoren nga mesuesi kur nxënësit hasin probleme gjatë procesit të të lexuarit:

a) Shpjegime direkte

b) I lë ta lexojnë dhe zgjidhin problemin vetë

c) Ju ofron pergjigjen e sakte

d) Jep udhezime dhe direktiva qe ju cojnë drejt pëergigjes së saktë 

e) Ndihmon studentet duke dhene nje celes
f) Të gjitha
g) Asnjera
h) Tjetër

3. A ju ofrohet kohë e mjaftueshme për të lexuar dhe analizuar një tekst në orën e mësimit?
a) $\quad \mathrm{Po}$
b) Jo
c) Shume pak
d) Mjaftueshëm
e) Nuk e di

4.Cilat nga teknikat e me poshtme njihni:
a) Diagramin e Venit
b) Krahasimi dhe kontasti
c) Harta e ngjarjeve
d) Shkak pasoje
e) Klasterin
f) KWL
g) Tabela e hirearkise
h) Asnjera
i) Tjetër

5.Cilat nga teknikat e mësipërme përdorni më shpesh në klasë? Listoni:

6. A perdoren tabela, struktura, grafiqe, harta , skicime etj. për të analizuar një tekst në klasë?

a. po b. jo c. ralle d. ndonjëhereë

7.Cilat nga llojet e pyetjeve te mëposhtme hasni me shume kur analizoni një tekst?

a) Kush, cili, Cfare?

b) Pse? Si ndodhi?

c) Si mendoni? Si iu duket? Si komentoni?

d) Si do te ndjeheshit ju? Po te ishit ne ate rast si do të vepronit?

8.Pasi lexoni një tekst cila nga alternativat e me poshtme mesuesja ju kerkon te beni:

a) Permblidhni tekstin

b) Thoni ngjarjet kryesore

c) Personazhet kryesore

d) Thoni idene e pergjithshme

e) Vazhdoni direkt me pyetjet

f) tre të parat

g) Asnjeren nga keto

h) Tjeter:

9.Gjate orës së mësimit mësuesja:

a) shpjegon të gjithë tekstin, fjali për fjali

b) analizon srukturat më të vështira gramatikore

c) stilin e të shkruarit

d) retorikën 
e) të gjitha këto

f) tjetër

Questions about Reading Comprehension strategies used bys students. Choose from 1 meaning Never to 5 , meaning Always.

1. I read quickly through the story to get the general idea before I read the story closely.

$$
\begin{array}{lllll}
1 & 2 & 3 & 4 & 5
\end{array}
$$

2. When I come to a part of the story that is hard to read, I slow my reading down.

$$
\begin{array}{lllll}
1 & 2 & 3 & 4 & 5
\end{array}
$$

3. I am able to tell the difference between important story parts and less important details.

$$
\begin{array}{lllll}
1 & 2 & 3 & 4 & 5
\end{array}
$$

4. When I read, I stop once in a while to go over in my head what I have been reading to see if it is making sense.

$$
\begin{array}{lllll}
1 & 2 & 3 & 4 & 5
\end{array}
$$

5. I adjust the speed of my reading by deciding how difficult the story is to read.

$\begin{array}{lllll}1 & 2 & 3 & 4 & 5\end{array}$

6. I stop once in a while and ask myself questions about the story to see how well I understand what I am reading.

$\begin{array}{lllll}1 & 2 & 3 & 4 & 5\end{array}$

7. After reading a story, I sit and think about it for a while to check my memory of the story parts and the order of the story parts.

$$
\begin{array}{lllll}
1 & 2 & 3 & 4 & 5
\end{array}
$$

8. When I get lost while reading, I go back to the place in the story where I first had trouble and reread.

$\begin{array}{lllll}1 & 2 & 3 & 4 & 5\end{array}$

9. When I find I do not understand something when reading, I read it again and try to figure it out.

$$
\begin{array}{lllll}
1 & 2 & 3 & 4 & 5
\end{array}
$$

10. When reading, I check how well I understand the meaning of the story by asking myself whether the ideas fit with the other information in the story.

$$
\begin{array}{lllll}
1 & 2 & 3 & 4 & 5
\end{array}
$$

11. I find it hard to pay attention when I read.

$$
\begin{array}{lllll}
1 & 2 & 3 & 4 & 5
\end{array}
$$

12. To help me remember what I read, I sometimes draw a map or outline the story.

$$
\begin{array}{lllll}
1 & 2 & 3 & 4 & 5
\end{array}
$$

13. To help me understand what I have read in a story, I try to retell it in my own words.

$$
\begin{array}{lllll}
1 & 2 & 3 & 4 & 5
\end{array}
$$

14. I learn new words by trying to make a picture of the words in my mind.

$$
\begin{array}{lllll}
1 & 2 & 3 & 4 & 5
\end{array}
$$

15. When reading about something, I try to relate it to my own experiences. 